\title{
Ontology and Technology in the Everyday
}

\author{
NERIJUS STASIULIS \\ Department of Philosophy and Cultural Studies, Faculty of Creative Industries, Vilnius Gediminas Technical University, Trakų St. 1, \\ 01132 Vilnius \\ Email: nerijus.stasiulis@vgtu.lt
}

\begin{abstract}
In this paper I try to discover a common thread which links issues discussed by various authors that may at first glance have little commerce with one another. The authors deal with different relations to reality that, I argue, inform our everydayness and technologies that permeat it. I consider the ontological issue of the real to be the unifying notion. Also, a tendency to disavow the human-centered stance on both theoretical and practical terms alongside abolishing the distance between man, or culture, and nature is apparent. The notion that technology does not have to be exploitative or destructive seems to also be an outcome of the mentioned shift in ontological terms. Our everyday dealings can be informed by notions that avoid dualisms such as different forms of anthropocentrism versus realism.
\end{abstract}

Keywords: culture, everyday, nature, ontology, technology

The question of the truth can be considered the principal one in philosophy. As it asks what truly is, it can also be named the question on isness, or "reality". Accordingly, the philosophical issue of the everyday is also nurtured by this principle question as the everyday unfolds along the horizon of the ever lost and found reality, and the "intensity" of its "isness" as manifested in everyday practices is precisely the measure of its "quality". Due to the crucial interconnection of current everydayness and current technology, the issue of the relation of technology to reality is also part and parcel of our current philosophical set-up. Hence, the present issue of Filosofija. Sociologija merges the themes of everyday, technology and ontology.

A common thread that may be noticed to run throughout each or most of the publications is dissatisfaction with any kind of boundaries and a longing for a sort of a more primordial unity. Adas Diržys comes up with his own take on the usual juxtaposition of the philosophies of Quentin Meillasoux and Eugene Thacker. The author emphasizes the need to give up making a distinction between thought and being, to disrupt their correlation. Deprivileging of the anthropocentrist view is here a crucial point. Also, life thought in terms of itself and giving up the principle of sufficient reason to accept a "necessity of contingency" is here the search for the final solution aimed at the ultimate reality.

Thus, although it may come as a surprise to the reader, I consider Seungbae Park's article dealing with issues of scientific realism versus antirealism in the philosophy of science akin in its problematics to that of Diržys whose discussion of rejecting the causal principle bears similarity to the antirealist stance. The common denominator may be the notion of the thing-in-itself which can be held responsible for various versions of scientific antirealism ${ }^{1}$ : our best theories

1 See, for instance, in Mach 1984 (fn30) how Immanuel Kant's notion of the thing-in-itself served to "awaken" one of the key antirealists in science, Ernst Mach. 
can only have the phenomenal quality whereas the richness of the thing-in-itself ensures that, as history proceeds, new anomalies and, consequently, novel theoretical frameworks to encompass them shall arise. However, such stance would leave us dissatisfied and could not be deemed philosophical as the aforementioned key principle of reality or truth would thus be abandoned for good. I hold that such longing for the principle of reality, despite its possible naivité, is at the root of the defense of scientific realism which Park undertakes. Creatively, he directs the problem of yet unobserved anomalies, namely against scientific antirealists themselves (contrary to the more usual and natural inclination to direct it against realists) when he eventually claims, essentially, that their position is plainly too "weak" to be held satisfactory. Perhaps, the everyday of the scientist could not be without accepting the principle of isness. A sharp distinction between the phenomenon and the thing-in-itself must, again, be somehow overcome.

Anyhow, science does not only presuppose the principle of the real but also serves to constitute our reality and everydayness under the guise of technology. While the latter has often been conceived in terms of its opposition to nature which has led to the exploitation of nature by humans for (and perhaps against) their own sake and to the so-called ecological crisis, the tendency to abandon distinctions and dualisms is remarkable here as well. Tomas Nemunas Mickevičius names Martin Heidegger as one of the many critics of anti-ecological moments of modernity but he also finds in his philosophy another trend - that of the positive appropriation of technology. The latter is, again, based on retracting the commonplace distinction of nature and technology to find that nature is in itself technological. Mickevicius sees a proof of this Heideggerian insight in the new science of synthetic biology. Hence, the issue of human enhancement raised and discussed by Grzegorz Holub falls into the same category. The Heideggerian manner of reflecting on such problems supposedly holds a promise of a more "real" experience of Being.

One can also find trends akin to the Heideggerian kind in the now popular rejection of the Cartesian thought and merging of the objective with the subjective and, hence, also seeing man and nature as forming an indivisible unity. The cultural side of ecology related to man and the natural side form a coherent unity. To experience this unity, however, perhaps a more embodied relation to reality ${ }^{2}$ is necessary rather than the one based on the abstract theory and privileging the sense of sight alone. The article co-authored by Sayedeh Parastoo Saeidi, Mohd Shahwahid Haji Othman, Dalia Štreimikienė, Parisa Saeidi, Abbas Mardani and Nerijus Stasiulis attemps to link trends in process philosophy and the phenomenological retrieval of embodiment with more practical manisfestations of emerging ecological consciousness. Eventually, they demonstrate how a shift in the thinking of employees of a corporation towards the ecology also serves as a means for the corporation to gain a competitive edge. It asserts a correlation between the changes in thought such as taking a more unitarian non-exploitative stance and the changes in practical everydayness such as the ecological attitudes being also the profitable ones.

Elizabeth A. Behnke ${ }^{3}$ works along the same lines as she proposes to adapt abstract notions of phenomenology (first of all, in its original Husserlian form) to reflect on the very practical and technological field of agriculture and also on different ways the sense "food" may be experienced. The thematization of these everyday experiences is supposed to transform our culture toward a more ecology-friendly one by undermining some of the ecologically unfriendly modes of relating to "food" and agriculture. "Food" and agriculture should be seen in a broader context of the experience of reality.

2 More on linking the embodied cognition to the issue of ecology see in, for instance, Gibson 1979.

3 E. A. Behnke has published on Edmund Husserl and the above-mentioned phenomenology of embodiment (see, for instance, Behnke, Ciocan 2012). 
If different senses of "food" can open different modes of experiencing reality, what about different senses of drinking? Jūratè Baranova discusses drinking of alcohol as a way to both transcend the everyday and access the deeper reality but ends up concluding that the best - and the most productive rather than destructive - way of intoxication is through plain water, i.e. being able to do so. She approaches this wisdom as a corollary of analyses of a number of instances of intoxication with alcohol (or drugs) in characters of literature or lives and ideas of famous authors whose biographies are wet with alcohol or high on narcotics. Disillusioned with the imperfections of the everyday or with the overperfections of rationality, one may seek the real in the thing-in-itself of the subconscious. Baranova, among other things, calls to our attention the reminder by Gilles Deleuze and Felix Guattari that it was perhaps through his use of cocaine that Sigmund Freud came to formulate his notion of the subconscious. According to them, however, pace Freud, the subconscious is to be constructed rather than discovered. Paradoxically, it is the very search for the principle of reality that gets one back to sobriety. This is what happened to Deleuze who had to give up drinking due to tuberculosis. His world-renowned philosophy is the result of intoxicating oneself with sobriety.

Could tourism also be considered a form of intoxication and is not some degree of sobriety necessary to guard urban heritage in the face of numerous everyday visitors from around the globe? The conference covered in the Chronicle discusses a city intoxicated with creativity - a creative city and the ways it does or can work to harmonize protecting urban heritage with education of both tourists and locals, perhaps, also by employing for this purpose novel technology that soaks the everyday in its quest for reality. Béla Mester who also took part in the conference publishes his article in the present issue of our journal to discuss the ups and downs of the model which seeks harmony between a city and its countryside, the duo reminiscent of the distinction between polis and ethnos and, accordingly, culture and nature.

Received 8 November 2017

Accepted 23 November 2017

\title{
References
}

1. Behnke, E. A.; Ciocan, C. 2012. "Introduction: Possibilities of Embodiment”, Studia Phaenomenologica 12: 11-16.

2. Gibson, J. J. 1979. The Ecological Approach to Visual Perception. Boston: Houghton Mifflin.

3. Mach, E. 1984. The Analysis of Sensations and the Relation of the Physical to the Psychical. Trans.

C. M. Williams. La Salle: Open Court.

\section{Ontologija ir technologija kasdienybejje}

\begin{abstract}
Santrauka
Straipsnyje siekiu surasti bendrą giją, siejančią problemas, aptariamas skirtingų autorių, kurie iš pirmo žvilgsnio galbūt turi mažai ką bendra. Jie aptaria skirtingus santykius su tikrove, kurie, manau, esmingai veikia mūsų kasdienybę ir ją pripildančias technologijas. Ontologinę tikrovess problemą laikau jų temas vienijančia mintimi. Be to, akivaizdžiai atsiskleidžia jiems bendra tendencija tiek teoriniu, tiek praktiniu lygmeniu atsisakyti antropocentrinès laikysenos ir panaikinti atstumą tarp žmogaus, kultūros ir gamtos. Suvokimas, kad technologijos nèra esmingai išnaudojančios arba destruktyvios, regis, taip pat yra minèto pokyčio ontologijoje padarinys. Mūsų kasdienị santykị su tikrove gali lemti sampratos, išvengiančios tokių dualizmų kaip ịvairių formų priešprieša tarp antropocentrizmo ir realizmo.
\end{abstract}

Raktažodžiai: gamta, kasdiena, kultūra, ontologija, technologija 